\section{MENTAL SYMPTOMS DUE TO INSULINOMATA}

\section{REPORT ON TWO CASES}

BY

\author{
J. TODD, M.B., B.S., D.P.M. \\ Consultant Psychiatrist, Menston Hospital \\ AGNeS D. COLlinS, M.B., D.P.M. \\ Assistant Psychiatrist, Menston Hospital
}

F. R. R. MARTIN, M.D., F.R.C.S.

Consultant Surgeon, St. Luke's Hospital, Bradford

AND

\section{K. E. DEWHURST, D.Phil., B.Litt., L.R.C.P.I.} D.P.M.

Wellcome Research Fellow, Corpus Christi College, Oxford; formerly Senior Registrar in Psychiatry, Littlemore Hospital, Oxford

Although Langerhans first described the pancreatic islets as long ago as 1869 , the possibility of recognizing the symptoms and signs of the hypoglycaemic state was non-existent until 1922, when Banting and Best extracted the first specimen of insulin from pancreatic tissue derived from dogs. Increasing awareness of the effects of the newly isolated hormone paved the way for the recognition of hypoglycaemia occurring as a natural phenomenon. Harris (1924), having "seen the insulin reaction in diabetic patients," reported the cases of five non-diabetic subjects who from time to time experienced symptoms suggestive of hypoglycaemia. Wilder, Allan, Power, and Robertson (1927) published the details of the first case in which a diagnosis of malignant islet-cell tumour had been made before death, the diagnosis having been verified at operation. Graham (1929) successfully removed an islet-cell tumour from the pancreas of a patient troubled by hypoglycaemic symptoms. Graham's pioneering feat was subsequently repeated many times, and by May, 1950, 398 cases of insulinoma had been reported (Howard, Moss, and Rhodes, 1960). From time to time during the last 26 years detailed studies and searching reviews have appeared in the literature respecting the aetiology, diagnosis, and treatment of the various forms of endogenous hypoglycaemia (Conn, 1940; Whipple, 1944 ; Crain and Thorn, 1949 ; Morley, 1952 ; Breidahl, Priestley, and Rynearson, 1955 ; Garland, 1958 ; Duncan, 1959).

Of the different kinds of endogenous hypoglycaemia, the variety that merits most attention is that due to the overproduction of insulin by an excess of islet-cell tissue, for the timely diagnosis of the condition will usually result in the full restoration of health (only $10 \%$ of islet tumours are malignant), whereas delayed recognition-if it does not prove fatal-may leave the patient with an irreparably damaged central nervous system (Aitken, 1936; Whipple, 1944 ; Richardson and Russell, 1952 ; Duncan, 1959). This supreme vulnerability of the central nervous system to hypoglycaemia prompted Morley (1952), when discussing insulin tumours of the pancreas, to speculate as follows: "It is possible that many neurological and psychiatric clinics shelter one or more of them undetected, for they are undoubtedly more common than the published records would suggest." The following two cases of islet-cell tumour are notable for the fact that both patients reached the hands of the surgeon via psychiatric hospitals.

\section{Case 1}

A housewife aged 56 was admitted to Menston Hospital (a mental hospital) on February 12, 1959, as a voluntary patient because she had been troubled by bouts of confusion, trance-like states, and spells of depression during the preceding four months.

Description of Symptoms. - The patient had little or no memory of most of her attacks, but her husband and two daughters were able to furnish objective accounts of these. She had her first attack when walking home from work. Her recollection of this attack was somewhat blurred, but she could remember that she became confused and that goods on display in shop windows seemed to be distorted in shape. Somehow she contrived to reach her home, where she wandered from one room to another in a state of increasing bewilderment, which culminated in her "seeing" herself surrounded by the entire contents of her five-roomed flat. She recovered from her confusion soon after drinking a cup of sweet tea prepared by her husband. A number of her attacks had been prolonged; for instance, she would perhaps go to bed one night "all right" and not "wake up " until the following night, having no recollection of what had transpired in the interim. She always awakened from these trance-like states with a throbbing headache and a mood of depression-a bout of crying being the rule. Her husband described another kind of attack thus: "She seemed to be laughing all the time. You could not understand what she said, her words were so slurred. She behaved like a little baby; she sat with her legs over the arm of a chair holding her little dog. She suddenly threw it from her, saying, 'I don't like you, you look horrible.' She had spasms of jerking her legs." Lastly, she had once developed a lurching gait in the street accompanied by a sensation of numbness around her mouth. She had noticed that she was especially prone to develop symptoms on washing or "spring-cleaning" days.

On admission she was noted to be drowsy, confused, and disorientated. However, she became more alert after drinking a cup of sweet tea, albeit she remained disorientated in all spheres. On examination there was no evidence of gross disease of the pulmonary, cardiovascular (B.P. 180/90), alimentary, or endocrine systems.

Blood-sugar values obtained during a prolonged study in which the patient's "home conditions" were reproduced are shown in the Table.

Some Blood-sugar Studies Before Operation. Patient's Diet, Including $300+\mathrm{g}$. of Carbohydrate Daily

\begin{tabular}{|c|c|c|c|}
\hline Date & $\begin{array}{c}\text { Times of } \\
\text { Blood-samples } \\
\text { in Hours } \\
\text { and Minutes }\end{array}$ & $\begin{array}{l}\text { Sugar-level in } \\
\text { mg. } 100 \mathrm{ml} \text {. } \\
\text { of Blood } \\
\text { (Folin-Wu) }\end{array}$ & Remarks \\
\hline $17 / 3 / 59$ & $\begin{array}{l}(10 \text { hrs. fast) } \\
7 \text { a.m. } \\
8 \\
12.30 \text { p.m. } \\
1 \text { p.m. } \\
5 \text {. } \\
6.30 \text { p.m. } \\
7.15 \%\end{array}$ & $\begin{array}{l}60 \\
35 \\
76 \\
78\end{array}$ & $\begin{array}{l}\text { (Home conditions reproduced } \\
\text { with "usual"- meals and } \\
\text { chores) } \\
\text { Breakfast } \\
\text { Lunch } \\
\text { Tea }\end{array}$ \\
\hline
\end{tabular}

Other Studies.-Blood: W.R. negative ; Hb, $75 \%$; bloodurea, $25 \mathrm{mg} . / 100 \mathrm{ml}$. ; serum cholesterol, $175 \mathrm{mg}$. $/ 100 \mathrm{ml}$; serum $\mathrm{Na}, 145 \mathrm{mEq} / 1$. ; serum $\mathrm{K}, 4.5 \mathrm{mEq} / 1$. ; $\mathrm{Cl}(\mathrm{NaCl})$, $105 \mathrm{mEq} / \mathrm{l}$. Urine: trace of protein; glycosuria absent on admission and during a glucose-tolerance test; ketosteroid output, $3.9 \mathrm{mg} . / 24$ hours. Liver-function tests: normal. $X$-ray studies of skull, abdomen, and lung fields N.A.D.

Putative diagnosis: Organic hyperinsulinism-? Islet-cell tumour. 
The patient was transferred to St. Luke's Hospital (a general hospital), Bradford, on May 29.

\section{Investigations and Treatment at St. Luke's Hospital}

Blood: Plasma sugar, $24 \mathrm{mg} . / 100 \mathrm{ml}$. (12-hr. fast ; King modified by Wright); plasma insulin $30 \gamma$ units $/ \mathrm{ml}$.

Operation.-On June 11 a small ovoid tumour 1 in. $(2.5 \mathrm{~cm}$.) long was removed by Mr. F. R. R. Martin (consultant surgeon) from the anterior surface of the body of the pancreas. No other tumours were detected. Convalescence was prolonged by a persistent discharge from a sinus track, but the patient ultimately left hospital on September 12.

Pathologist's report : benign islet-cell tumour of pancreas.

Comparison of Pre-operative and Post-operative data.A pre-operative and post-operative glucose-tolerance test series compared as follows.

Pre-operative (18-hr. fast; $100 \mathrm{~g}$. glucose; Folin-Wu):

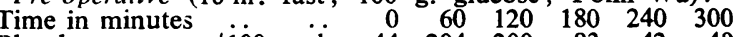

$\begin{array}{lllllllll}\text { Blood-sugar mg./100 mi. } 44 & 204 & 200 & 83 & 42 & 48\end{array}$

Post-operative (24-hr. fast ; 100 g. glucose ; Folin-Wu) :

$\begin{array}{lllllllll}\text { Time in minutes } & \ldots & \ldots & 0 & 60 & 120 & 180 & 240 & 300\end{array}$

$\begin{array}{llllllrr}\text { Blood-sugar mg./100 } & \text { mi. } & 91 & 220 & 83 & 78 & 85 & 91\end{array}$

Comparative E.E.G. studies are shown in Figs. 1-3.

She was seen at an out-patient clinic on April 27, 1961, and stated that she felt in excellent mental and physical health.

Comment.-This case has some noteworthy features. The overt manifestations of the patient's hypoglycaemia assumed several different forms, a state of affairs which shows that the versatility of this condition extends to the production of a number of different syndromes in addition to a host of individual symptoms. The potent effect of physical exertion on the level of the bloodsugar is shown by the patient's increased liability to attacks of hypoglycaemia on the days when she worked hardest, and by the fact that the second lowest bloodsugar value $(35 \mathrm{mg} . / 100 \mathrm{ml}$.) obtained in the course of

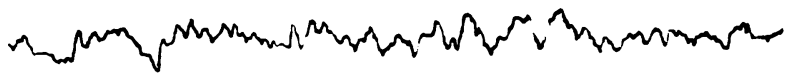

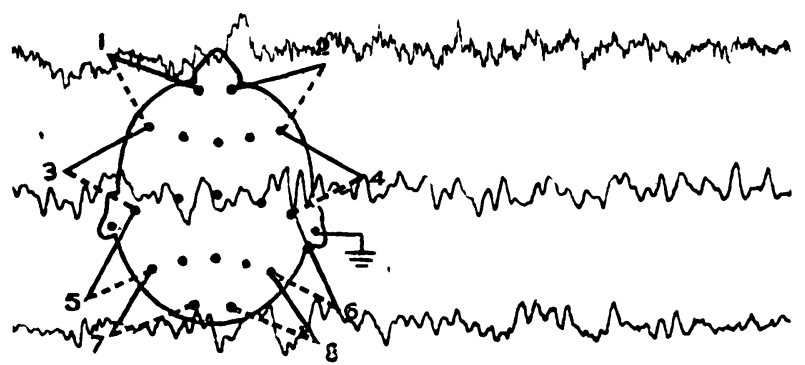

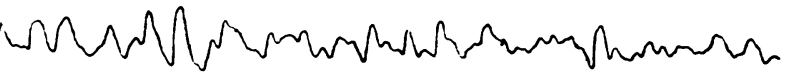

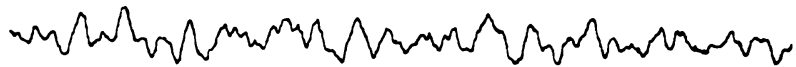

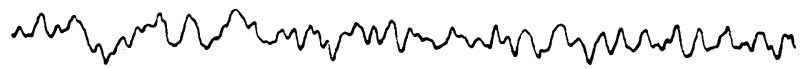

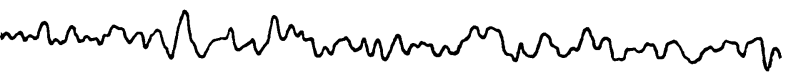

$I 50 \mu \mathrm{V}$

$$
\text { one second }
$$

Fig. 1.-Case 1. E.E.G. abnormal. March 13, 1959, 10.45 a.m. Frequent diffuse irregular H.V. slow waves. Blood sugar $40 \mathrm{mg}$. $100 \mathrm{ml}$. at commencement of recording. investigations was during the test in which she performed her "usual" household chores. The prompt recovery (from an attack) which occurred after she had drunk a cup of sweet tea was a significant feature of the medical history. Judging from the results obtained with electroencephalography, this form of investigation would seem to offer a valuable means of checking the progress of insulinoma cases after a successful operation.

Case 2

A man aged 31 was admitted to the Ashhurst Clinic (psychiatric), Oxford, on September 9, 1957, with a provisional

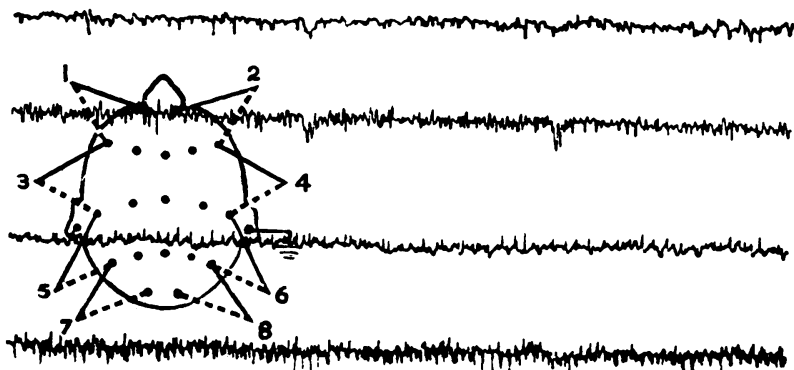

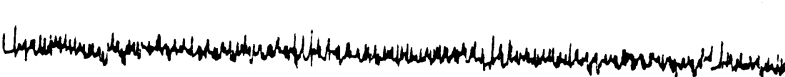

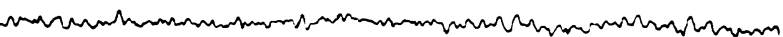

\section{$I 50 \mu \mathrm{V}$ one second}

FIG. 2.-Case 1. E.E.G. March 13, 1959, 11.35 a.m. H.V slow waves no longer in evidence, alpha rhythm of $9 \mathrm{c} / \mathrm{s}$ present. Blood sugar $130 \mathrm{mg} . / 100 \mathrm{ml}$. after intravenous administration $\mathrm{mg} .100 \mathrm{ml}$. after intraven
of $200 \mathrm{ml}$. glucose $(10 \mathrm{~g}$.).
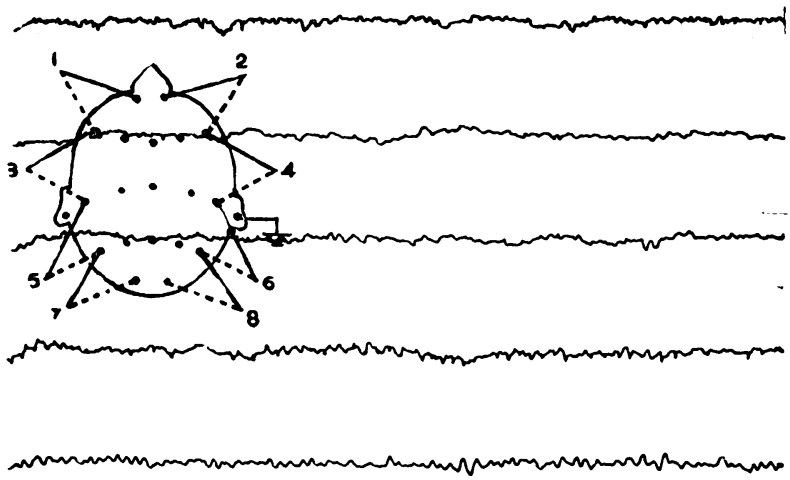

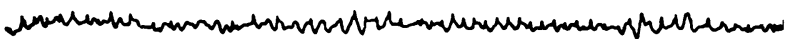

\section{$I 50 \mu \mathrm{V}$}

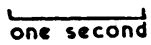

FIG. 3.-Case 1. Routine E.E.G. December 7, 1959. Activity of alpha frequency $9 \mathrm{c} / \mathrm{s}$ present associated with beta activity. No H.V. slow waves. Blood sugar $87 \mathrm{mg} . / 100 \mathrm{ml}$. at commencement of recording. 
diagnosis of temporal-lobe epilepsy and personality disorder. Five years earlier he had sustained an injury to his head as the result of a motor-cycle accident. He was rendered unconscious for about two hours, and had several hours of post-traumatic amnesia. He was detained in hospital for some six weeks.

Two and a half years before admission to the Ashhurst Clinic he had suddenly felt ill while gardening. He succeeded in reaching his bedroom before collapsing and losing consciousness. He felt quite well within a few minutes of regaining consciousness, but his doctor placed him on a regimen of anticonvulsant tablets. A few months later he began to have similar attacks, especially when he indulged in vigorous exercise or missed a meal. These attacks were indistinguishable from grand-mal epilepsy, as loss of consciousness preceded convulsive movements of the limbs and (sometimes) urinary incontinence. Before a fit he tended to become restless, argumentative, and aggressive. The continuity of his thinking was interrupted by spells of amnesia. Epilepsy did not run in his family.

\section{Results of Physical Examination and Special Investigations}

Physical examination revealed no abnormality of the central nervous system or any other system. The skull $x$-ray films and C.S.F. were normal. An E.E.G. showed a mild theta dysrhythmia with no localizing features. A glucose-tolerance test (12-hr. fast; $50 \mathrm{~g}$. glucose ; Folin-Wu) gave the following results:

$$
\begin{array}{llllrrrr}
\text { Time in minutes } & \ldots & \ldots & 0 & 30 & 60 & 90 & 120 \\
\begin{array}{l}
\text { Blood-sugar mg./100 ml. } \\
\text { Glycosuria, nil. }
\end{array} & \ldots & 83 & 125 & 110 & 103 & 83 \\
\end{array}
$$

The patient had no fits while in hospital, and he was discharged home on October 18, 1957. He returned to work, but his fits became more frequent. After he had a series of nocturnal fits his wife left home and went to live with her parents. The day before she left her husband he had "walked around waving his arms like a madman." This mode of behaviour had so terrified her that she had locked herself and her child in another room and summoned the police. He was readmitted to the Ashhurst Clinic on June 18, 1959. The results of physical examination and special tests were again essentially negative. A glucose-tolerance test (conditions as before) gave the following results:

$$
\begin{array}{llrrrrrr}
\text { Time in minutes } & & 0 & 30 & 60 & 90 & 120 & 150 \\
\begin{array}{l}
\text { Blood-sugar mg./100 } \\
\text { Glycosuria, nil. }
\end{array} & \text { mi. } & 85 & 135 & 130 & 100 & 98 & 81
\end{array}
$$

However, his attacks were noted to occur most frequently three to four hours after he had finished his lunch and in the small hours of the morning. During one attack in the late afternoon he passed into a state of confusion accompanied by muscular spasms, profuse sweating, and dilated pupils. Moreover, blood-sugar values of 55 and $33 \mathrm{mg} . /$ $100 \mathrm{ml}$. respectively were obtained while he was in the throes of two other epileptiform attacks. Lastly, a fit which showed no signs of remitting spontaneously was promptly terminated by an intravenous injection of $25 \mathrm{ml}$. of $50 \%$ glucose.

Putative diagnosis: Spontaneous hypoglycaemia-? Isletcell tumour of the pancreas.

The patient was transferred to the Radcliffe Infirmary, Oxford, on June 25.

\section{Investigations and Treatment at Radcliffe Infirmary}

Blood: $\mathrm{Hb}, 113 \%$; blood urea, $32 \mathrm{mg} / 100 \mathrm{ml}$. Liverfunction tests normal. Urinary ketosteroid output, $10.3 \mathrm{mg} . /$ 24 hours.

Glucose-tolerance test (12-hr. fast ; 50 g. glucose ; Kingsley-Reinhold)

Time in

$\begin{array}{llllllllllll}\text { minutes } & \ldots & 0 & 30 & 60 & 90 & 120 & 150 & 180 & 210 & 240 & 270\end{array}$

Blood-sugar

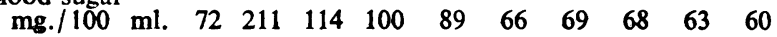

The glucose-tolerance test was'terminated by an intravenous injection of $10 \mathrm{ml}$. of $50 \%$ glucose when blood-sugar had dropped to $60 \mathrm{mg} . / 100 \mathrm{ml}$., as the patient bad a fit at this point.

In an unsuccessful attempt to control his attacks he was put on two-hourly feeds and a diet yielding 4,700 calories a day.

Operation.-On July 8, 1959, Professor P. R. Allison operated on the patient and removed a small, red, slightly lobulated tumour from the posterior aspect of the body of the pancreas. During the operation the patient sweated profusely, but the sweating ceased within a few minutes of removal of the tumour.

The post-operative course was in general uneventful. Fasting blood-sugar values of 122,124 , and $143 \mathrm{mg} . / 100 \mathrm{ml}$., respectively, were obtained during the first three days after the operation, and a transient glycosuria was noted during the first 10 days of the post-operative period. A glucosetolerance test (conditions as before) was performed on July 19 , and gave the following results:

Time in

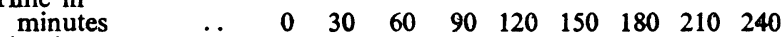

$\begin{array}{lllllllllll}\begin{array}{l}\text { Blood-sugar } \\ \text { mg./100 ml. }\end{array} & \text {.. } & 111 & 159 & 128 & 115 & 106 & 96 & 97 & 98 & 125\end{array}$

Pathologist's report: benign islet-cell tumour of the pancreas.

Follow-up Studies.-He was discharged from hospital on July 27, and was last seen in September, 1961, when he likened his post-operative course to "starting a new life." He had remained free from fits. His wife, who had returned to her husband immediately after his discharge from hospital, affirmed that he had shown no abnormality of mood or behaviour since his operation.

Comment.-An intriguing feature of this case is the deceptive nature of the history, for the onset of such symptoms as emotional instability, aggressive behaviour, amnesic episodes, and epileptiform seizures may well follow a severe head injury. The aptness of both physical exertion and fasting to precipitate manifestations of hypoglycaemia in subjects with insulinomata is clearly demonstrated here. The prominence of various forms of motor excitement during the patient's hypoglycaemic phases is noteworthy. Crain and Thorn (1949), in their comprehensive study of islet-cell tumours of the pancreas, state that $24 \%$ of patients (195 studied) with such tumours exhibited clonic convulsions. The validity and usefulness of the triad of diagnostic criteria proposed by Whipple (1938) and the inadequacy of the standard glucose-tolerance test are well illustrated in this case.

\section{Discussion}

Diagnosis of Hypoglycaemia and Organic Hyperinsulinism

When it has been shown that a subject is given to attacks of endogenous hypoglycaemia the medical history considered in conjunction with the results of physical examinations, urine tests, prolonged sugartolerance tests, blood-sugar estimations in the fasting state, liver function tests, and endocrine-function tests should enable the physician to distinguish between the various modes of hypoglycaemia. These are: hypoglycaemia due to functional (stimulative) hyperinsulinism; hypoglycaemia due to organic hyperinsulinism (islet-cell tumour or hyperplasia); and hypoglycaemia due to extrapancreatic factors such as hepatic, adrenal, and pituitary insufficiency. It is now generally accepted that a prolonged fast is of great diagnostic value in the case of suspected organic hyperinsulinism, for in the positive case suspicious symptoms ultimately develop during the fast in association with a low blood-sugar level. It is noteworthy that Breidahl, Priestley, and Rynearson (1956) hold that the period of starvation may have to 
be extended to 72 hours before organic hyperinsulinism can be confidently excluded. Happily, there is reason to believe that patients might be spared these marathon fasts by combining starvation with muscular activity (see Case 5-Morley, 1952).

The presence of organic hyperinsulinism can be confidently inferred if the requirements of Whipple's (1938) triad are fulfilled. These are: the advent of neuropsychiatric symptoms after fasting ; a concomitant blood-sugar level below $50 \mathrm{mg} . / 100 \mathrm{ml}$.; and banishment of symptoms by the administration of glucose.

\section{Summary}

The literature relating to endogenous hypoglycaemia is briefly reviewed. Two cases of hypoglycaemia due to insulinomata of the pancreas are described, mental symptoms so dominating the clinical picture that the patients were admitted to psychiatric hospitals. The abolition of all symptoms by successful operations for the removal of the tumours are recorded. Points of particular interest in the case reports are commented upon, and the differential diagnosis of hypoglycaemia is discussed.

We regret that shortage of space prevents our thanking all those to whom we are indebted for assistance with these cases, but we are especially grateful for the help we have received from Dr. M. J. Parsonage (director) and Dr. J. Dundas (assistant), of the E.E.G. Department of the General Infirmary at Leeds; Mr. J. T. Towers, chief laboratory technician of Menston Hospital ; Professor P. R. Allison, professor of surgery in the University of Oxford ; and $\mathrm{Mr}$. J. R. P. O'Brien, Nuffield Director of Chemical Biochemistry at the Radcliffe Infirmary, Oxford.

\section{REFERENCES}

Aitken, L. F. (1936). Med. Clin. N. Amer., 20, 393.

Breidahl。 H. D., Priestley, J. T., and Rynearson, E. H. (1955). Ann. Surg., 142. 698.

_ (1956). J. Amer. med. Ass., 160, 198.

Conn, J. W. (1940). Ibid., 115, 1669.

Crain, E. L., and Thorn, G. W. (1949). Medicine (Baltimore), 28, 427.

Duncan, G. G. (1959). Diseases of Metabolism, 4th ed. Saunders, London and Philadelphia.

Garland, H. (1958). Brain, 81, 485.

Graham, R. R (1929). Cited by G. Howland, W. R. Campbell, E. J. Maltby, and W. L. Robinson, J. Amer. med. Ass. $1929,93,674$.

Harris, S. (1924). Ibid., 83, 729.

Howard, J. M., Moss, N. H., and Rhodes, J. E. (1950). Int. Abstr. Surg., 90, 417.

Morley, J. (1952). Brit. J. Surg., 40, 97.

Richardson, J. E., and Russell, D. S. (1952). Lancet, 2, 1054

Whipple, A. O. (1938). J. int. Chir., 3, 237.

(1944). Surgery, 16, 289.

Wilder, R. M., Allan, F. N., Power, M. H., and Robertson H. E. (1927). J. Amer. med. Ass., 89, 348 .

A recommendation that the use of motor horns should be forbidden at all times in built-up areas, except when necessary to avoid danger, is one of the chief points made by the Committee on the Problem of Noise in its interim report to Lord Hailsham, Minister for Science. The committee also recommends that legislation should be introduced to ensure that new vehicles when tested should not exceed certain defined noise levels; that drivers making unnecessary noise should be liable to prosecution; and that further research should be done on developing a meter which is better suited to the measurement of vehicle noise than those at present available, and into the principles of reducing noise from motor vehicles. Drivers, concludes the report, play an essential part in cutting down the noise that vehicles make.

\section{BRL 1621: A COMPARISON WITH OTHER ISOXAZOLYL PENICILLINS}

\author{
BY
}

R. KNOX, M.D., F.R.C.P. Professor of Bacteriology

D. M. MacLAREN, M.B. Lecturer in Bacteriology

J. T. SMITH, Ph.D. Lecturer in Bacteriology

J. A. P. TRAFFORD, M.B., M.R.C.P. Medical Registrar

AND

\section{R. D. S. BARNES, M.B.}

Registrar in Clinical Pathology

Guy's Hospital and Medical School, London S.E.1

Many isoxazolyl penicillins (Doyle et al., 1961) have been synthesized, and three (BRL 1400, 5-methyl-3-phenyl4-isoxazolylpenicillin; BRL 1577, 5-methyl-3-p-chlorphenyl-4-isoxazolylpenicillin; and BRL 1621, 5-methyl3-o-chlorphenyl-4-isoxazolylpenicillin) were selected as being the most promising for clinical use. Clinical results using BRL 1400 (P 12) have been reported elsewhere (White and Smith, 1962; Bunn and Amberg, 1961), and given here is a clinical comparison of the other two with a laboratory study of all three isoxazolyl penicillins suggesting that the best of the three is BRL 1621 (marketed as "orbenin").

\section{Materials and Methods}

Ten patients were treated with BRL 1577 and 18 with BRL 1621 in a dosage of 0.25 to $0.5 \mathrm{~g}$. four times daily for 7 to 10 days. Clinical response to treatment, serum concentrations, and the sensitivity of staphylococci to the isoxazolyl penicillins were assessed as described by Trafford et al. (1962).

In the investigation of methicillin-resistant organisms $0.02 \mathrm{ml}$. amounts of $1 / 100$ diluted broth cultures were inoculated on the surface of agar plates containing penicillin and the results read after 9 hours' incubation.

\section{Results}

Infections with Staphylococci.-Ten patients with infections due to penicillinase-producing coagulasepositive staphylococci were treated with $0.5 \mathrm{~g}$. of BRL 1577 four times daily by mouth. Four patients with pneumonia responded satisfactorily and one with septicaemia failed to respond until he was given methicillin. Of five patients with abscesses and wound infections in various sites who were treated two failed to respond and three improved satisfactorily.

The reasons for the failure of the drug in these three cases were analysed. In one patient a chronic fistula had developed following appendicectomy. After treatment with BRL 1577 staphylococci were again cultured, though in reduced numbers, and as the clinical effect of the drug was negligible the antibiotic therapy was changed. The other patient had a post-mastectomy wound infection from which staphylococci were eliminated during treatment, but post-treatment cultures were again positive.

In contrast the organism was not eliminated from the third patient, who had a staphylococcal septicaemia, and 